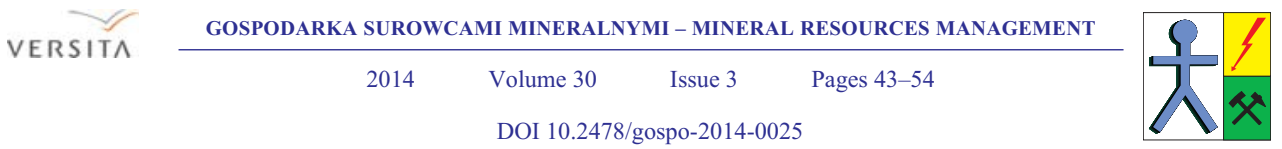

\title{
Analysis of Results of Spatial Development Plans for Management of Rock Raw Material Deposits
}

\section{Introduction}

Resources of rock raw material deposits are elements of natural capital. Every action aimed at economic, social, or ecological development of all regions should take into account possibilities presented by the natural environment, since this is an area of communal responsibility. It is the natural environment that determines the actual advantages of a particular region. These advantages constitute both its aesthetic qualities and competitiveness. Entities managing a certain space and taking advantage of natural resources and qualities in order to satisfy social needs shape the particular natural, social, economic, technical, technological, as well as spatial structures (Dubel 2000). This means a clear interdependence of social and economic development and the natural environment where economic growth is not possible without maintaining a proper standard of quality. At the same time, the economic system exerts pressure on the environment, for instance, through the location of new investments. Thus problematic situations can develop where a compromise is difficult to reach. The optimal use of natural resources is therefore a multidimensional issue where one must take into consideration administrative and legal conditions as well as natural and spatial qualities, factors understood to be parts of planning and organizing spatial use (Kaźmierczak 2002; Szamałek 2011; Samimi Namin et al. 2011).

* Ph.D. Eng., Wrocław University of Technology, Faculty of Mining, e-mail: urszula.kazmierczk@pwr.wroc.pl 


\section{Organization of Spatial Management by the State}

Matters concerning areas intended for particular purposes and determination of their management are settled under the Polish Act of 27 March 2003 on spatial planning and land development. The Act provides for the fact that shaping a commune spatial policy; including passing the study of conditions and directions of commune spatial development (Study) and local land development plans (except for internal marine waters, territorial sea and an exclusive economic zone, as well as compounds), is the task of the commune (pursuant to Article 3, paragraph 1). What is more, determining land use, public investment project distribution, land management methods, and land development conditions takes place in the local land development plan (in case of a lack of a local land development plan, land management methods and land development conditions are determined by means of decisions on land management and development conditions) (pursuant to Article 4, paragraph 1). This plan settles the spatial distribution of objects of different environmental and economic functions. It is a guarantee of spatial order, which means not only aesthetic qualities, utility, logic, and clarity of spatial structure, but also high usability and effectiveness harmonized with nature, both nationally and locally (Kaźmierczak 2002; Kaźmierczak and Malewski 2003).

The local land development plan is the last phase of spatial policy, and its determination is conditioned by the preparation of many other planning documents (Fig. 1). This is mostly due to the fact that spatial development should be integrated and comprehensive not only at the local but also at the regional level. Therefore, it is the task of government administration (that is, the Council of Ministers) to shape and pursue state spatial policy, which determines environmental, cultural, social, and economic conditionings, as well as objectives and directions of this policy. The concept of spatial policy concerning national development is the basis for drawing up programmes including government tasks aimed at the implementation of public investment projects of state significance. At the voivodeship (regional/provincial) level, the government's task is to shape and pursue the spatial policy of the voivodeship. A regional assembly passes a voivodeship development strategy determining conditions, objectives, and directions of voivodeship development, and a spatial development plan which specifies methods of spatial structure organization, including programmes containing government tasks aimed at implementation of public investment projects of supralocal significance (Article 4, 38, 39, 42, 47, 48 of Act of 27 March 2003 on spatial planning and land development).

Pursuant to Article 4 of the Act of 27 March 2003 on spatial planning and land development, determining land use, public investment project distribution, as well as land management methods and land development conditions takes place in the local land development plan. Prior to assembling the local land development plan, a commune is obliged to prepare a study of conditions and directions of commune spatial development, which, though not an ordinance, still results in settlements based on this study being binding for commune authorities regarding local planning (Article 9). The Study is the basic tool of 


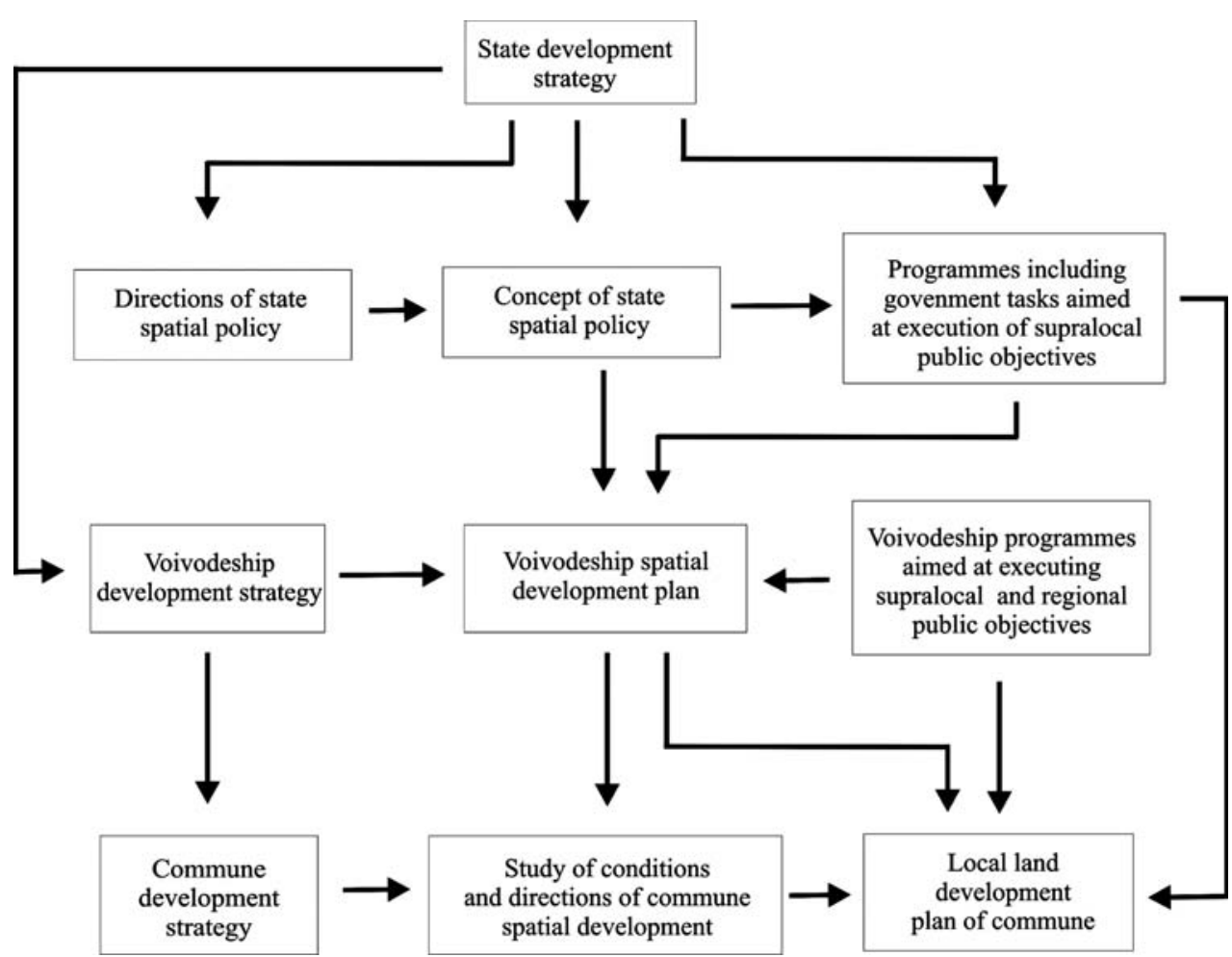

Fig. 1. Scheme of actions connected with drawing up a document essential to implementation of spatial policy

Rys. 1. Schemat działań związanych z opracowywaniem dokumentów niezbędnych przy realizacji polityki przestrzennej

forward-looking management and it determines the spatial policy of a commune. Moreover, the Study should include settlements of voivodeship development and land development plan strategies, as well as commune development strategy which the communes are not under an obligation to provide. Despite the lack of this obligation, most communes draw up a development strategy regardless, resulting in different methods and degrees of taking advantage of the environment, as well as different preferences and traditions of local communities.

\section{Rock Raw Material Deposits in Spatial Development Plans}

The piece of legislation addressing all the components of the environment, specifying general provisions and basic definitions, is the Environmental Protection Law Act of 27 April 2001 (Dz.U.2008, no. 25, item 150). Section VI of the act, Environmental protection with spatial development and with investment implementation, obliges communes to maintain an environmental balance and sustainable management of natural resources considering, 
for example, areas of mineral deposits. The present and future needs related to mining of these deposits is also to be considered (Article 72) in the Study of conditions and directions of commune spatial development (Study) and in local land development plans (Polish abbreviation: $m p z p$ ). Furthermore, the provisions of Article 10 of the Act on spatial planning and land development emphasize that the Study considers conditions resulting, among other things, from the existence of documented mineral deposits and mining areas determined pursuant to separate provisions (that is, Geological and Mining Law, Dz.U.2011, No. 163, item 981), as well as areas for which a commune intends to draw up a local land development plan.

The presence of a deposit could be included in the Study and mpzp provided that it is documented. A raw material deposit may be considered documented only after an approval of geological documentation of the specific deposit. The approval is granted by means of the decision of a competent authority of the geological administration (in case of a lack of a local land development plan, land management methods and land development conditions are determined by means of decisions on land management and development conditions (in case of rock raw materials, the geological administration authorities are Voivodeship Marshals represented by voivodeship geologists and starostas - represented by Poviat geologists). After the geological documentation has been approved, the competent authority of the geological administration is obliged, pursuant to Article 94 of the Act of 9 June 2011, Geological and Mining Law (Dz.U.2011, No. 163, item 981), to send a copy of any decisions concerning geological documentation to the executive authorities of local governmental units regarding the area subjected to the geological documentation (Article 94 of the Geological and Mining Law).

Further analysis of the Geological and Mining Law indicates that Article 95 provides that documented mineral deposits shall be included in studies of conditions and directions of commune spatial development, local land development plans, as well as in Voivodeship area development plans in order to protect the deposits. It should be done within 2 years from the date of the geological documentation's approval if not a voivode attaches the area of the documented mineral deposit to the Study and issues a supplementary order. The study drawn up in this way produces the same legal effects as the Study of conditions and directions of commune spatial development. The costs of drawing up the Study are entirely borne by the commune with the area that is the subject of the supplementary order (Article 96). Furthermore, it is worth noting that establishing the limits of a mineral deposit in the Study and $m p z p$ of a commune is not tantamount to establishing the land's use for mining. Only the change of land use and determining a method of development in an mpzp is the basis for exclusion of land from the previous use and the possibility of mining activity (whereas from Article 111, paragraph 1b, the result is that a motion for exclusion of classes IV, IVa, IV, V and VI produced from soil of mineral origin from agricultural production is binding for the authority allowing for excluding soil from the production, and the decision is of a declarative nature) (Article 14 of the Act on spatial planning and land development, Articles 7 and 11 on the protection of agricultural and forest land). 
In practice, deposit development is not a matter of priority for many communes, and other ways of developing the area over the deposit are often used here which; in consequence, make mining of mineral deposit impossible. Revealing the existence of mineral deposits in the трzр of commune means neither banning infrastructure or housing development, nor requiring adjustment of the plan in a way that makes mining of the revealed deposit possible. For instance, the building of A4 motorway, which crosses great deposits of sand and gravel in Tarnowo-Borowiec and Gosławice area, will preclude developing these deposits (Nieć and Radwanek-Bąk 2009). What is more, another hindrance for mining are restrictive requirements concerning environmental protection and a process of expanding forms of this protection; e.g. through Natura 2000 network. In Dolnośląskie Voivodeship itself, there are 39 documented and unexploited rock mineral deposits of joint reserves of 985.2 million $\mathrm{Mg}$ within the legally protected areas (Kaźmierczak 2014). In Polish Natural Landscape Parks there are 9 deposits, and a complete mining ban has been enforced for 8 of those. Therefore, deposit protection, despite the declarations in the Environmental Protection Law and the Geological and Mining Law, is insufficient. This issue has been already recognized and discussed in the literature on the subject (Nieć and Radwanek-Bąk 2009, 2011; RadwanekBąk 2007, 2008, 2008a, 2009; Uberman 2010; Kasztelewicz and Ptak 2011; Wojtacha et al. 2012). As the result of discussions and expert studies, proposals of solutions have been made. One of these is the proposal of Nieć and Radwanek-Bąk (2011a, 2011b, 2012). They introduce two variants of detailed proposed solutions. The first variant consists in framing a separate act on mineral reserves. This proposal is based on the Act on the protection of agricultural and forest land. The essence of this Act can be reduced to valorisation of deposits and areas, their future occurrence as protected objects, restrictions concerning using deposit and raw material areas for the purposes making mining of deposits impossible, presentation of the plan of the management of deposits and areas and their future occurrence in a study of conditions of spatial development, introduction of fees for reclassification of deposit areas for other purposes than a mining activity and sanctions for non-observance of statutory principles of their protection. One should mention here that the basic condition of deposit protection; that is, evaluation of deposits, was implemented for the whole area of Poland between 2011 and 2013 within the framework of the project co-financed by the European Regional Development Fund under the Innovative Economy Operational Program entitled Strategies and Scenarios of Development and Use of Rock Mineral Deposits. On the other hand, the second variant of solving the issue of protection of deposits concerns amendments to the existing legislation and implementation of provisions connected to protection of deposits. The most significant elements of this proposal are gradation of mineral deposit protection based on their evaluation and the duty of preparing reserve management plans. Another interesting solution concerning a purpose of an area in planning documents is taking economic advantages of the area into consideration (Uberman 2010). According to this proposal, in case of attempts to use areas over the mineral deposits for other purposes than mining in the Study or the mpzp, there should be a possibility of evaluating cost-effectiveness of the area. Still, despite the ongoing discussion and ready proposals, the 
issue of deposit protection remains unsolved which; in consequence, may constitute a threat to the raw material safety in relation to mineral deposits in the future.

Another stage of deposit management is its mining, which can be carried out only on the basis of an acquired mining concession. Establishments of the mpzp for a commune determines the granting of such a concession, since its issuing is dependent on an agreement with a competent commune head, town or city mayor (Article 16, paragraph 5 of the Geological and Mining Law). This agreement takes place on the basis of the mpzp for the commune, and in case of a lack of this document, on the basis of the Study. This is the stage when the legislator provides for the possibility of a concession authority's denial to grant the concession in a situation where the intended mining activity would hinder the use of the property according to its purpose determined with the mpzp. In case of a lack of this document, it would hinder the use of this property in a way established in the Study or in separate provisions (Article 29.1 of Law on the protection of agricultural and forest land).

Here again the issue of deposit protection arises. In case of no approval of commune in relation to deposit development, revealing it in the Study and the mpzp is of no significance since the commune may determine a function of an area within these documents according to its non-mining preferences. Obviously, in case of commune's approval in relation to the mining of documented deposit and a lack of relevant provisions in the Study and mpzp concerning revealing it, the procedure of amendments to the provisions of the plan may be initiated. However, amendments to the Study or mpzp are made via the same procedure that is applied for their passing and can take a few years (Article 27 of the Act of 27 March 2003 on spatial planning and land development). What is more, pursuant to Article 104, paragraph 1 of the Geological and Mining Law, mining terrains and areas are mentioned in the Study and in the and terrain specified for the certain deposit). Additionally, in cases where mining could have a considerable impact on the environment, for mining terrain or some part thereof, one could draw up a local land development plan (on the basis of spatial development provisions). Drawing up such a plan is optional for communes; that is, it is only drawn up when a municipal council enacts a resolution on the necessity of drawing up such a plan. The plan is drawn up by a commune and costs are borne by a mining entrepreneur (Article 104 of the Geological and Mining Law). Here, one should question rationality of drawing up this plan within the currently required scope. All the actions connected with environmental protection and providing public safety, which are required in a local land development plan for a mining terrain, are analysed in detail during the procedure of environmental impact assessment, which is finished with issuing a decision on environmental conditions of the consent to implement an undertaking (the so-called environmental decision), as well as, taken into account in a deposit development project (Polish: projekt zagospodarowania złoża (pzz)). These two documents, that is, $p z z$ and environmental decision, should be presented by an entrepreneur together with an application for mining concession. The procedure of environmental impact assessment is difficult and long-lasting. It determines, analyses and assesses a direct and indirect influence on the environment, possibilities and methods of 
preventing and reducing the negative influence on the environment, and monitoring range. All the impacts of a planned undertaking are investigated in the stages of implementation, exploitation and liquidation of undertaking. What is more, according to Article $56 \mathrm{~Pa}-$ ragraph 9 of the Act on Environmental Protection Law (Dz.U.2001.62.627 as amended), the decision on environmental conditions is legally binding in relation to concession for mining of deposits. This means that the concession cannot violate the decision of environmental conditions and it must take these conditions into consideration. On the other hand, pzz does not require a formal approval; still, it is assumed that, as an attachment to the application for the concession, it is approved with issuing the concession.

The last stage of deposit management is the phase where the deposit has been exploited (cessation of mining activity) and the post-exploitation terrain is prepared for a use other than mining. A mining entrepreneur is legally obliged to take land reclamation actions after deposit exploitation. The terrain must be reclaimed in order to prepare it for the target redevelopment in a way that it could function in accordance with the pursuant to Article 4 on spatial planning and land development. Here the situation becomes complicated, since determining future functions of mineral mining terrain - which should be mentioned in the Study and mpzp of the commune - is essential. Determining these functions often turns out to be very difficult since the duration of mineral exploitation is sometimes a period of as much as several decades, during which time social, economic, and political circumstances can change significantly. An additional problem is the fact that a mining entrepreneur is legally obliged to take land reclamation actions, while development falls within the competence of a future user of reclaimed land, who is not always a mining entrepreneur. Here is a certain difficulty of analysing the problem connected with the notion of land value which is dependent on its utility functions. This value will be different for private and public owners. Additionally, taking into consideration that the costs of reclamation actions depends on a chosen direction of reclamation, and a method of development of transformed areas always determines the direction of reclamation, there is a conflict of interest between an entrepreneur and a future user. An entrepreneur will always aim at reducing reclamation costs, and a future user at increasing the value of reclaimed land. Determining a proper period of applying for a decision on the direction of reclamation by an entrepreneur also raises difficulties. As it turns out, this period is not precisely determined by legislation which promotes delaying this duty till the end of deposit exploitation. Still, an entrepreneur should have reclamation needs carefully determined at the beginning of the activity since reclamation costs can be reduced by optimizing an exploitation process. Information essential here is connected with plans of future development of particular land and technical parameters which should be obtained at the end of reclamation process; namely, shape of space, quality of soil, quality of water, status of geotechnical safety, status of ground water quality, greenery quality, status of communication, access of third parties to a reclaimed land, etc. Bearing these limitations in mind, an entrepreneur can conduct exploitation coupled with the process of reclamation by proper planning and performing of mining works. Therefore, very often, communes determine possibilities of future reclamation 
when land for exploitation of deposits is selected in the трzр. In case of one of the mines of natural aggregate, the direction of reclamation was defined in variants as: agricultural, forest or recreational. On the other hand, when a commune does not determine a function of land after deposit exploitation in the mpzp; the most often, an entrepreneur applies for a reclamation decision together with own proposal.

\section{Summary}

The mechanism for shaping spatial development policy is rather complex and difficult to administrate since it requires combining economic, social, and ecological issues. Its final results are local land development plans, which determine the place, time, and method of using a certain space. A mining activity must be subordinate to the rules of spatial planning, especially as it is impossible to commence exploitation without the prior establishment of the land's use in the commune spatial development plan for this kind of activity. This is provided for by the Act of 7 July 1994 on spatial development, pursuant to which the establishment of use and methods of land development are mentioned in the local land development plan of a commune. It is worth bearing in mind that commune councils, through passing the mpzp of the commune, are strictly bound by the Study's establishments. Land use functions in the Study are not the same as land use functions in the mpzp of a commune since the results are different. Land use in the Study is important for passing the plan. On the other hand, the land use in the трzр of a commune can bring results for external entities such as mining entrepreneurs. This would, however, have a notable financial effect since amendments to the Study and mpzp of a commune mean costs borne by the commune. In contrast, execution of a local mining terrain development plan would mean the costs are borne by the mining entrepreneur.

The development of raw material deposits is not possible after approving changes just to the land's use in the Study and mpzp of a commune. One should also exclude soil overlying the deposit from the previous use. This exclusion is made by means of a decision in the mpzp. This also could affect results for the excluding party (a mining entrepreneur) in connection with drawing up proper documentation, resulting in costs such as annual fees (concerns soil of mineral and organic origin of I, II, III, IIIa, IIIb classes - article 11 paragraph 1a on the protection of agricultural and forest land) and, in the case of forest lands, a single compensation for exclusion of lands. As a further consequence (after the change of land use), the result can be higher fees for industrial land use. The last stage of deposit management is the termination of mining activity, which is connected with reclamation and redevelopment of lands after deposit exploitation. This means that after reclamation and redevelopment, the affected land will be used for other purposes than those connected with mining activity. Its functions must therefore be in accordance with the establishments of the Study and mpzp of the local commune. This situation also creates the necessity of implementing amendments to establishments of the Study and mpzp of the commune (unless these have been previously implemented). 
The analysis of results of spatial policy also showed that rock raw material deposits are protected insufficiently. The basic problems are a possibility of developing the area over the deposit for non-mining purposes, dispersion of ownership of land over the deposit, and the protection of animate nature resources. Despite the ready proposals often presented in the literature on the subject, and worked-out method of evaluation of rock mineral deposits and its implementation for the whole area of Poland, the issue of deposit protection has not been solved yet and it has not drawn attention of authorities deciding on the strategy of economic and social development, as well as, local authorities. Therefore, the following problems of deposit protection have not been solved yet:

- recognizing deposit protection as a public purpose,

- framing an act on deposit protection or proper amendments to the provisions of the Environmental Protection Law, Geological and Mining Law, and legislation concerning spatial development,

- low social awareness concerning the role of mining in economic and civilisation development of the society.

This scientific work was financed within the framework of the project entitled "Strategie $i$ Scenariusze Technologiczne Zagospodarowania i Wykorzystania Ztóż Surowców Skalnych” [Technological Strategies and Scenarios of Development and Use of Raw Rock Material Deposits] co-financed by the European Regional Development Fund within the framework of the Innovative Economy Operational Programme and with partial financing thanks to Statute Research Studies (order S 20 133)

\section{REFERENCES}

Dubel, K. 2000. Natural conditionings in proces of spatial planning. Białystok: Wyd. Ekonomia i Środowisko, 160 p. (in Polish).

Kasztelewicz, Z. Ptak, M. 2011. Protection of non-developed mineral deposits as the most important guarantor of existence and development of the Polish surface mining. Przegląd Górniczy 8, pp. 20-26 (in Polish).

Kaźmierczak, U. 2014. Abailability of rock raw materials in the context of legally protected areeas of the Voivodeship. Gospodarka Surowcami Mineralnymi - Mineral Resources Management 30(2), pp. 35-50 (in Polish).

Kaźmierczak,U. Malewski, J. 2003. The rationalization of the decision-making in planning reclamation direction [W:] Środulska-Wielgus, J. Wielgus, K. Panek, R. red. Kształtowanie krajobrazu terenów poeksploatacyjnych w górnictwie. Międzynarodowa konferencja naukowa. Kraków. 10-12 grudnia 2003. Biuro Usług Komputerowych Stanisław Smaga, pp. 331-338 (in Polish).

Kaźmierczak, U. 2002. Economic, nature and spatial functions of rock mining in the Wroclaw region. Doctor's thesis. Wrocław, 100 p. (in Polish).

Nieć, M., Radwanek-Bąk, B. 2012. Protection of mineral deposits as an element of planning and land development - formal and mental problems. Przeglad Górniczy 8, pp. 3-6 (in Polish).

Nieć, M., Radwanek-Bąk, B. 2011. The protection of mineral resources - a way of a difficult compromise. Przeglad Górniczy 10, pp. 7-15 (in Polish).

Nieć, M., Radwanek-Bąk, B. 2011a. Proposal of legal protection of unmanaged deposits of minerale. Discussion article. Kraków: Polish Akademy of Sciences - Committee of Mineral Economy Sustainable Development, 75 p. (in Polish). 
Nieć, M., Radwanek-Bąk, B. 2011b. Proposal of legal protection of unmanaged deposits of minerale (Discussion article). Bezpieczeństwo Pracy i Ochrona Środowiska w Górnictwie 7(203), pp. 12-17 (in Polish).

Nieć, M., Radwanek-Bąk, B. 2009. Recent utilization of mineral deposits in Poland and threats to security of supply. Przeglad Geologiczny 7, pp. 5-97-599 (in Polish).

Radwanek-Bąk, B. 2009. Mineral deposits accessibility as a basic condition for mineral deposits management. Cz. 2. Mineral Resources and Building Machines 1, pp. 18-20 (in Polish).

Radwanek-Bąk, B. 2008. Mineral deposits accessibility as a priority for mineral resources protection. Surface Mining 2-3, pp 19-24 (in Polish).

Radwanek-Bąk, B. 2008a. Mineral deposits accesibility as a basic condition for mineral deposits management. Cz. 1. Mineral Resources and Building Machines 6, pp. 20-23 (in Polish).

Radwanek-Bąk, B. 2007. Directions and barrier of mineral resources protection. [In:] Current and perspectives of mineral resources management Zakopane, 14-16 listopada 2007. Kraków: Bulletin of the Mineral and Energy Economy Research Institute of the Polish Academy of Sciences, pp. 213-228 (in Polish).

Samimi Namin i in. 2011 - Samimi Namin, F., Shahriar, K. i Bascetin A., 2011, Environmental impact assessment of mining activities. A new approach for mining methods selection. Gospodarka Surowcami MineralnymiMineral Resources Management 27(2), pp. 113-143 (in Polish).

Szamałek, K. 2011. Ratonal mineral deposit management in the light of mineral resouces theory. Gospodarka Surowcami Mineralnymi - Mineral Resources Management 27(4), pp. 5-15.

Uberman, R. 2010. Problems of management of extraction of rocky raw resulting from regulations of the law on spatial planning, Scientific Papers of the Insitute of Mining of the Wrockaw University of Technology 37, pp. 279-293 (in Polish).

Wojtacha i in. 2012 - Wojtacha, P. Mgłosiek, J. Janduła, J. 2012 Management of mineral seposits from the point of view of spatial planning in relations to geological and mining law. Bulletin of the Mineral and Energy Economy Research Insitute of the Polish Academy of Sciences 83, s. 205-221 (in Polish).

SPiLD 2003. Act of 27 March 2003 r. on spatial planning and land development (Dz.U.2003.80.717 z późn. zm.) (in Polish).

EPL 2001. Act of 27 April 2001 r. Environmental Protection Law (Dz.U.2001.62.627) (in Polish).

GML 2011. Act of 9 June 2011 r. Geological and Mining Law (Dz.U.2011.163.981) (in Polish).

PAFL 1995. Ustawa z dnia 3 lutego 1995 r. on the protection of agricultural and forest land (Dz.U.1995.16.78) (in Polish).

\title{
ANALIZA SKUTKÓW PLANÓW ZAGOSPODAROWANIA PRZESTRZENNEGO DLA GOSPODARKI ZLOŻAMI SUROWCÓW SKALNYCH
}

\author{
Słowa kluczowe
}

zagospodarowanie przestrzenne, gospodarka złożem, działalność górnicza, surowce skalne

\section{Streszczenie}

W publikacji omówiono mechanizm kształtowania polityki planowania przestrzennego, którego ostatnim elementem są miejscowe plany zagospodarowania przestrzennego, rozstrzygające o rozmieszczeniu w przestrzeni obiektów spełniających różne funkcje przyrodnicze i gospodarcze. Plany zagospodarowania przestrzennego są gwarantem ładu przestrzennego, który oznacza zarówno walory estetyczne, funkcjonalność, logikę, czytelność i jasność struktury przestrzennej, jak i zharmonizowane z przyroda, wysoką użyteczność i efektywność we wszystkich skalach, od lokalnej do krajowej. Przygotowanie takiego planu poprzedzone jest przygotowaniem wielu innych opracowań. Związane jest to z tym, że planowanie przestrzenne powinno odbywać się w sposób zintegrowany, kompleksowy, 
nie na szczeblu lokalnym, lecz regionalnym. W artykule przedstawiono także skutki, jakie wywołuje polityka przestrzenna na każdym etapie gospodarowania złożem od momentu jego udokumentowania do rekultywacji terenów pogórniczych oraz poruszono problemy związane z niedostateczną ochroną złóż w dokumentach planistycznych. Udokumentowane złoża surowców skalnych muszą być ujawnione w Studium uwarunkowań i kierunków zagospodarowania przestrzennego gmin oraz miejscowym planie zagospodarowania przestrzennego, a także $w$ Planach zagospodarowania przestrzennego województwa. Brak takiego zapisu skutkuje odmową udzielenia koncesji na eksploatację złoża, która nie jest możliwa bez wyłączenia gruntów z dotychczasowej działalności. W przypadku ostatniej fazy działalności górniczej, tj. rekultywacji terenów po eksploatacji kopalin, obszar ten musi być zrekultywowany i przygotowany do zagospodarowania w taki sposób, aby mógł pełnić funkcje zgodne z ustaleniami Studium uwarunkowań i kierunków zagospodarowania przestrzennego gmin i miejscowego planu zagospodarowania przestrzennego danej gminy. Oznacza to konieczność zmian zapisów w tych dokumentach, jeśli wyprzedzająco nie określają docelowych funkcji terenu nad złożem.

\section{ANALYSIS OF RESULTS OF SPATIAL DEVELOPMENT PLANS FOR MANAGEMENT OF ROCK RAW MATERIAL DEPOSITS}

Key words

spatial development, deposit management, mining activity, rock raw materials

Abstract

This publication describes a mechanism for shaping the policy of spatial development, the final outputs of which are local land development plans determining the spatial distribution of objects of different environmental and economic functions. Land development plans guarantee a spatial order, which means not only aesthetic qualities, utility, logic, and clarity of spatial structure, but also high usability and effectiveness harmonized with nature, both nationally and locally. Working out such a plan is determined by drawing up many other planning documents. This results from the fact that spatial development should be integrated and comprehensive not only at the local but also at the regional level. What is more, the article presented the results of spatial policy at every stage of deposit management, from a deposit documentation to a post-mining area reclamation, as well as, it discussed issues connected with inadequate protection of the deposits in the planning documents. Documented rock raw material deposits must be included in a study of conditions and directions of commune spatial development (Polish: Studium uwarunkowań i kierunków zagospodarowania przestrzennego gmin) and in a local land development plan (Miejscowy plan zagospodarowania przestrzennego), and also in voivodeship area development plans. Admittedly, this mention does not protect the deposit from being used for non-mining purposes; still, lack of it might result in failure to obtain the concession for mining of deposits, which is not possible without exclusion of land from the previous use. As for the last phase of mining activity - that is, area reclamation after mining of mineral deposits - such ans area must undergo reclamation and be prepared for development in a way that enables it to function in accordance with the study of conditions and directions of commune spatial development and in the land development plan of the particular commune. This means the necessity of amendments to these documents unless they have already defined target functions of deposit area. 
